\title{
Quality Parameters of Composite Membranes for Microencapsulation: Evaluation by Statistical Optimization
}

\author{
Kamaldeen Oladimeji Salaudeen ${ }^{1, ~ *, ~ A r i a h u ~ C h a r l e s ~ C h u k w u m a ~}{ }^{2}$, Yusufu Muhammed Ikagu ${ }^{2}$ \\ ${ }^{1}$ Nigerian Stored Products Research Institute (NSPRI), Kano Station, Nigeria \\ ${ }^{2}$ Department of Food Science and Technology, University of Agriculture, Makurdi, Nigeria
}

Email address:

ksk_deen@yahoo.com (K. O. Salaudeen)

${ }^{*}$ Corresponding author

\section{To cite this article:}

Kamaldeen Oladimeji Salaudeen, Ariahu Charles Chukwuma, Yusufu Muhammed Ikagu. Quality Parameters of Composite Membranes for Microencapsulation: Evaluation by Statistical Optimization. International Journal of Food Engineering and Technology.

Vol. 3, No. 2, 2019, pp. 13-24. doi: 10.11648/j.ijfet.20190302.11

Received: August 13, 2019; Accepted: August 29, 2019; Published: November 5, 2019

\begin{abstract}
Optimization of formulations in the manufacture of membrane is necessary to obtain the optimum concentration of base materials and plasticizer. The research was aimed to determine the optimum composition of the blends and that of the plasticizers in the manufacture of soy-protein isolate and cassava starch based membrane intended for food micro-particles. Soy-protein isolate and cassava starch blends were prepared and mixed at different proportions $(100: 0 \% ; 90: 10 \% ; 80: 20 \%$; 70: $30 \% ; 60: 40 \% ; 50: 50 \%$ and $0: 100 \%)$. Glycerol and sorbitol plasticizer were also prepared and mixed at different proportions (100: $0 \% ; 80: 20 \%$ and 60: 40\%). The experiment was conducted using response surface (User-Defined) method on design expert (version 11.1.0) software package. The response values of the membrane such as solubility, water vapor permeability, elongation at break, and puncture strength were best fitted into quadratic model while that of the tensile stress was best fitted into linear model considering their values of predicted $\mathrm{R}^{2}$ and adjusted $\mathrm{R}^{2}$. The optimum formulation for the manufacture of the composite membrane is $\mathrm{B}_{4}\left(70 \%\right.$ soy-protein isolate and $30 \%$ cassava starch) and $\mathrm{P}_{2}(80 \%$ glycerol and $20 \%$ sorbitol) with the desirability value of 0.039 . These optimum formulations provide responses for the membrane parameters as membrane thickness of $0.24 \mathrm{~mm}$, vapor permeability of $16.06 \mathrm{~g} \mathrm{H}_{2} \mathrm{O} \mathrm{mm} \mathrm{m}$ day $\mathrm{kPa}$, membrane solubility of $45.95 \%$, tensile stress of $20.71 \mathrm{MPa}$, elongation at break of $13.65 \%$ and puncture strength of $2.37 \mathrm{kN}$.
\end{abstract}

Keywords: Membrane, Modelling, Optimization, Soy-protein Isolate, Cassava Starch

\section{Introduction}

Microencapsulation refers to a technology in which the bioactive components are completely enveloped, covered and protected by a physical barrier without any protrusion [1]. In recent years, food industry requires the addition of functional compounds such as bioactive molecules (e.g. antioxidants, minerals, vitamins, phytosterols, lutein, fatty acids, lycopene) and living cells (e.g. probiotics) into food products and these compounds are usually highly susceptible to environmental, processing and/or gastrointestinal conditions. Therefore, microencapsulation had been utilized for effective protection of these compounds $[1,2]$. In microencapsulation technology, the sensitive substance to be encapsulated can be called the core while the material used to envelope or cover the sensitive substance is called the membrane [2, 3]. Different materials, widely accepted as membranes during drug encapsulation, have not been approved for use in the food industry, because many of these materials have not been certified for food applications as "generally recognized as safe" (GRAS) materials [2] and for this reason, bio-polymers were seen as suitable materials for the capsules membrane. Several researchers had successfully utilized bio-polymers as membranes for encapsulation of food active compounds [1, 4-8]. Bio-polymers which can be inform of edible coatings or edible films are flexible materials used in food coating and packaging [9]. Recently, considerable research has been conducted to develop the bio-polymers from a variety of bioproducts [10]. Such bio-products include starches, cellulose derivatives, gums, proteins (animal or plant-based) and lipids $[11,12]$. These edible bio-products offer the possibility of 
obtaining thin films and coatings to cover fresh or processed foods to extend their shelf life. Bio-polymers offer extra advantages such as edibility, biocompatibility, esthetic appearance, barrier to gasses properties, non-toxicity, nonpolluting and its low cost [13]. This study is to optimize the blend and plasticizer compositions of the composite membrane. Optimization is the systematic formulation design required to minimize the number of trials, and analyze effect of the different compositions by the response surfaces for each quality parameter to obtain the appropriate formulations for optimum value of each quality parameter [14]. Optimization of the formulation using response surface methodology has been carried out on bio-polymers with a basis of whey protein, tapioca starch, corn starch, chitosan, tapioca starch and chitosan composite, xanthan gum, tapioca starch composite and plasticizer compositions [15-21] but no research had been reported on statistical optimization of the compositions for the soy-protein isolate and cassava starch based composite membrane. There is therefore the need to model and optimize the blends compositions (soy-protein isolate and cassava starch) and the plasticizer compositions (glycerol and sorbitol) in development of the composite membrane.

\section{Materials and Methods}

\subsection{Source of Raw Materials}

Fresh sweet cassava tubers were procured from "Yankaba" market, Kano State, Nigeria. Soy protein isolate powders (natural flavor) was purchased from puritan's pride at shop online: www.puritan.com and delivered by Konga (Kano state branch).

\subsection{Extraction of Cassava Starch}

A wet extraction method as described by [22] was used for cassava starch extraction. Three kilograms of fresh cassava tuber was manually peeled, washed with clean water and crushed to produce pulp. The pulp was suspended in cold deionized water and sieved through a mesh $(0.45 \mathrm{~mm})$; the fibrous materials was removed leaving the starch solution. The starch layer was suspended in deionized water and centrifuged six to seven times until the settled starch gives a firm, dense deposit on the bottom and is substantially free of fine fibre. The starch was recovered by filtration and dried at $55^{\circ} \mathrm{C}$ for $12 \mathrm{~h}$ and milled into powder. Figure 1 shows flow chart for cassava starch production.

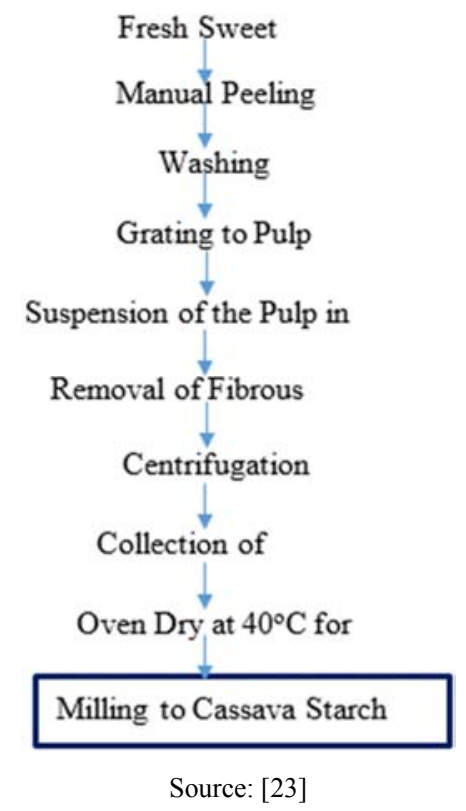

Figure 1. Flowchart for production of cassava starch.

\subsection{Development of the Composite Membrane}

\subsubsection{Blend Formulation}

Soy-protein isolate (SPI) and Cassava starch were blended at different compositions $\left(\mathrm{B}_{1}=100: 0 \% ; \mathrm{B}_{2}=90: 10 \% ; \mathrm{B}_{3}=\right.$ $80: 20 \% ; \mathrm{B}_{4}=70: 30 \% ; \mathrm{B}_{5}=60: 40 \%, \mathrm{~B}_{6}=50: 50 \%$ and $\mathrm{B}_{7}=$ $0: 100 \%)$. An electric blender was used in order to achieve homogenous blends.

Table 1. Soy protein and Cassava Starch Blend Formulation Ratio.

\begin{tabular}{|c|c|c|c|c|c|c|}
\hline $\mathrm{B}_{1}(\mathrm{~S}: \mathrm{C}) \%$ & $\mathrm{~B}_{2}(\mathrm{~S}: \mathrm{C}) \%$ & $\mathrm{~B}_{3}(\mathrm{~S}: \mathrm{C}) \%$ & $\mathrm{~B}_{4}(\mathrm{~S}: \mathrm{C}) \%$ & $\mathrm{~B}_{5}(\mathrm{~S}: \mathrm{C}) \%$ & $\mathrm{~B}_{6}(\mathrm{~S}: \mathrm{C}) \%$ & $\mathrm{~B}_{7}(\mathrm{~S}: \mathrm{C}) \%$ \\
\hline 100:0 & $90: 10$ & $80: 20$ & $70: 30$ & $60: 40$ & $50: 50$ & $0: 100$ \\
\hline
\end{tabular}

Note: $\mathrm{S}: \mathrm{C}=$ Ratio of Soy-protein isolate and Cassava starch

\subsubsection{Preparation of the Membrane}

Casting method described by [24] was used for the development of the composite membranes. All soy-protein isolate and cassava starch blend compositions $\left(\mathrm{B}_{1}, \mathrm{~B}_{2}, \mathrm{~B}_{3}, \mathrm{~B}_{4}\right.$, $\mathrm{B}_{5}, \mathrm{~B}_{6}$, and $\left.\mathrm{B}_{7}\right)$ and plasticizer's compositions $\left(\mathrm{P}_{1}=\right.$ glycerol, $\mathrm{P}_{2}=$ glycerol: sorbitol $(80: 20)$ and $\mathrm{P}_{3}=$ glycerol: sorbitol $(60: 40))$ were utilized in the membrane development as shown in table 2. [23] concluded that addition of up to $20 \%$ glycerol level enhanced the sensory, mechanical and barrier properties of cassava starch-soy-protein concentrate edible films. Based on this, $20 \%$ of all the plasticizer compositions were used. Below are procedural steps followed during development of the membranes.

1. Preparation of membrane forming suspension

i. $20 \%$ of each Plasticizer composition ( $\mathrm{v} / \mathrm{w}$ of the blends) was added to $200 \mathrm{ml}$ of distilled water

ii. $10 \mathrm{~g}$ of each composite blends ratio was also added making $5 \%(\mathrm{w} / \mathrm{v})$ of overall distilled water content independently of plasticizer. The solution was homogenously mixed together using magnetic stirrer

iii. The $\mathrm{pH}$ of the membrane-forming suspension was adjusted to 9.98 with $1 \mathrm{M}$ sodium hydroxide and the $\mathrm{pH}$ of the solution was ascertained using $\mathrm{pH}$ meter.

2. Cross-Linking of the Suspension by Heat 
i. The membrane-forming suspension was heated in a beaker on a hot plate at $90^{\circ} \mathrm{C}$ for $5 \mathrm{~min}$ with continuous stirring using a glass rod to obtain the membrane-forming solution.

ii. The membrane-forming solution was cooled to $40^{\circ} \mathrm{C}$

3. Casting of the Membranes

i. The membrane forming solution was casted onto flat, levelled, non-stick trays to set.

ii. Once set, the trays were held overnight in an oven at $35^{\circ} \mathrm{C}$ before peeling the membranes off the plates to enable complete setting of the membranes.

4. Conditioning of the membranes

i. Membrane samples were conditioned prior to evaluation at $52 \%$ relative humidity and $25^{\circ} \mathrm{C}$ temperature in desiccators over diluted sulphuric acid solution for $72 \mathrm{~h}$.

Flowchart for production of the membrane is shown in figure 2. figures 3 and 4 are pictorial view for drying and conditioning of the membrane respectively.

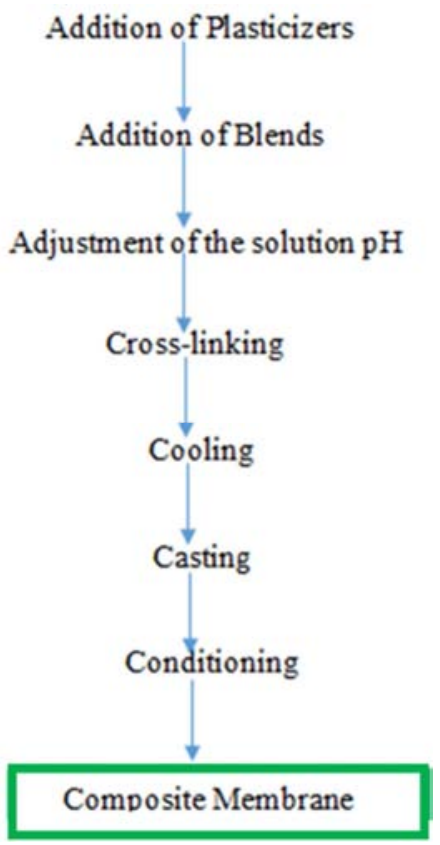

Source: [23]

Figure 2. Flowchart for the membrane production.

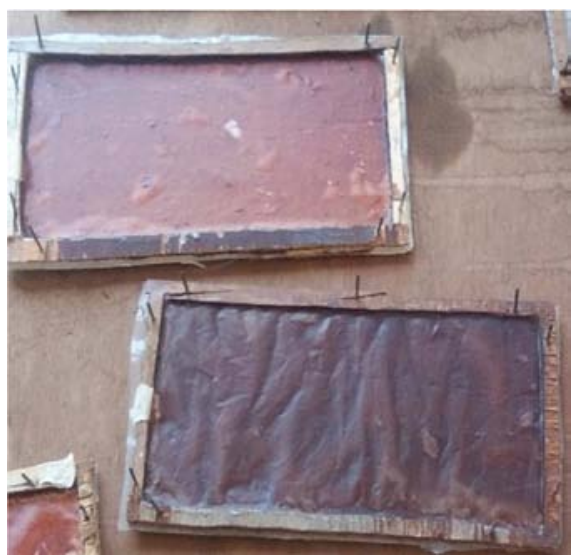

Figure 3. Drying of the bio-polymer.

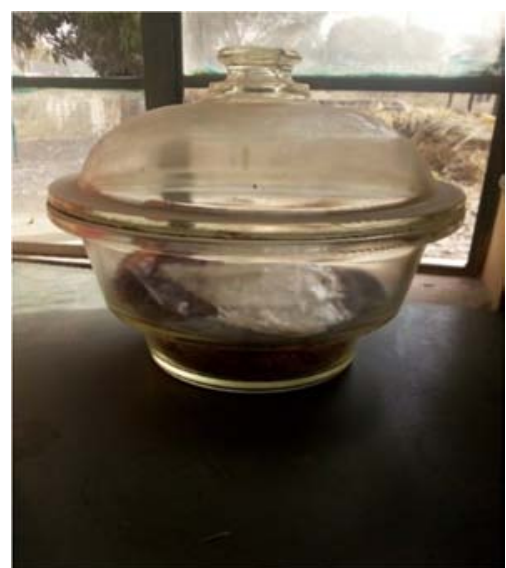

Figure 4. Conditioning of the bio-polymer.

Determination of the Membrane Quality Parameters

\subsection{Effect of Blend and Plasticizer Compositions on Quality Parameters of the Membranes}

Effect of blend and plasticizer compositions on the membrane quality parameters such as film thickness, water vapour barrier, membrane solubility, mechanical properties (tensile strength, elongation at break and puncture strength), were determined.

\subsubsection{Membrane Thickness Measurement}

Thickness of the membrane as affected by blends compositions and plasticizers type was measured using electronic digital Vernier caliper. The thickness of each membrane was measured randomly in six different parts of the membrane and the average value was taken as the membrane thickness. Figure 5 show pictorial view of the digital Vernier caliper.

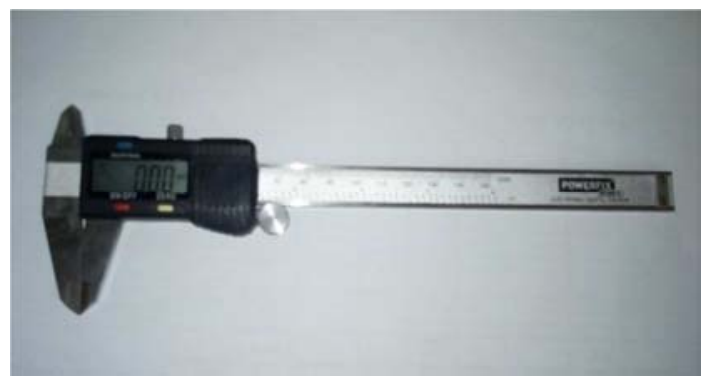

Figure 5. Digital Vernier caliper

\subsubsection{Water Vapor Barrier of the Membrane}

The method of [25] with slight modification was used for the evaluation of water vapor permeability (WVP) of the membrane. In this method, glass dishes containing distilled water to a level of $1 \mathrm{~cm}$ from the top so as to impart a $\mathrm{RH}$ of $100 \%$ was closed with the membrane samples. Silicon gum was used to make it an airtight unit. All the prepared samples were kept in desiccators maintained at $25^{\circ} \mathrm{C}$ and $52 \%$ relative humidity using diluted sulphuric acid solution. Further, these desiccators were kept at $38^{\circ} \mathrm{C}$ in the incubator. The water vapours transferred through the bio-polymer was determined by measuring the weight changes periodically until constant 
weight is reached. Weight loss was plotted over time to obtain water vapor transmission rate $(\mathrm{C})$ which is the slope of the linear regression of weight loss vs. time of the biopolymer samples. WVP was calculated from the equation given by [25] as:

$$
W V P=\frac{C X}{A \times \Delta P}\left(\mathrm{~g} \mathrm{H}_{2} \mathrm{O} \mathrm{mm} \mathrm{m}^{-2} \text { day } \mathrm{kPa}\right)
$$

Where $\mathrm{X}$ is the bio-polymer thickness $(\mathrm{m}), \mathrm{A}$ is area of the exposed bio-polymer $\left(\mathrm{m}^{2}\right), \mathrm{C}$ is the slope of the weight loss of the dish, to the nearest $0.0001 \mathrm{~g}$, vs. time and $\Delta \mathrm{P}$ is the partial vapor pressure difference $(\mathrm{Pa})$ across the two sides of the bio-polymer. Partial vapor pressure of the liquid $\left(\mathrm{H}_{2} \mathrm{O}\right.$ and diluted $\mathrm{H}_{2} \mathrm{SO}_{4}$ ) across the two sides of the bio-polymer was determined using psychometric chart.

\subsubsection{Membrane Solubility}

The solubility of bio-polymer samples which is a parameter of biodegradability of bio-polymer was determined according to the method described by [26]. Bio-polymer samples were dried at $105^{\circ} \mathrm{C}$ for $24 \mathrm{~h}$ and weighed $\left(\mathrm{W}_{1}\right)$. Each sample was then immersed into in $50 \mathrm{~mL}$ conical flask containing $20 \mathrm{~mL}$ of $1 \mathrm{M}$ hydrochloric acid solution. The conical flasks were capped using cocks and placed in a shaking water bath for $24 \mathrm{~h}$ at $25^{\circ} \mathrm{C}$. The solution was then filtered, and the residues remained on the filter paper was dried in an oven at $105^{\circ} \mathrm{C}$ for $24 \mathrm{~h}$ after which the samples was weighed to determine the dry matter soluble in water $\left(\mathrm{W}_{2}\right)$. Solubility was calculated using the formula given by [26] as:

$$
\% \text { Film solubility }=\frac{w_{1}-w_{2}}{w_{1}} \times 100
$$

\subsubsection{Mechanical Properties of the Membranes}

Mechanical properties such as tensile stress, elongation at break, and puncture strength were determined using manually operated mechanical testing machine for bio-polymer which was locally fabricated for this research purpose. Parts of this machine include digital force gauge, grips, screw and frame as shown in figure 6 .

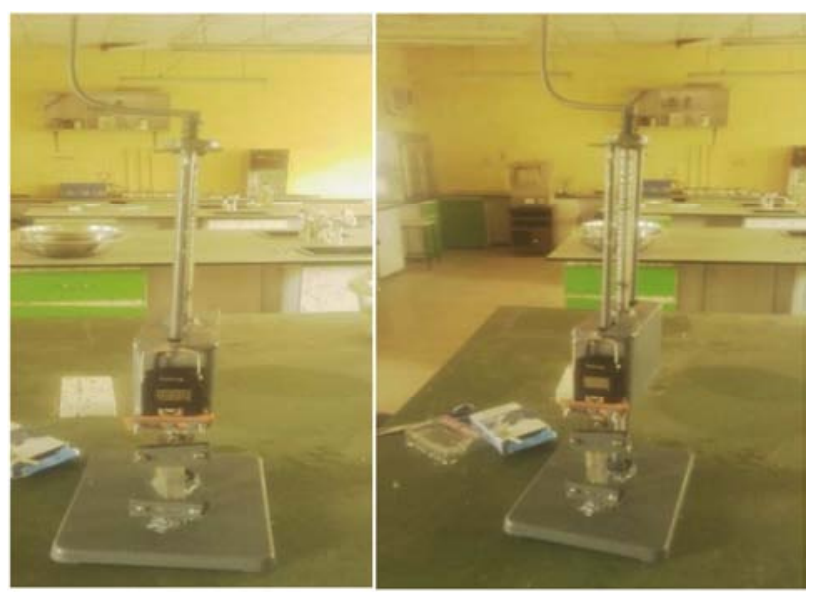

Figure 6. Manually operated mechanical testing machine for edible films.

\section{Constructed by: Kamaldeen Oladimeji Salaudeen}

i. Tensile strength (TS)

Membrane strips $(30 \times 60 \mathrm{~mm})$ were mounted to grips of the digital mechanical testing machine. Manually rotating the screw of this machine enables pulling of the membrane strips vertically upward and the reading of the force applied was measured by the digital force gauge. The maximum force required to rupture each membrane sample was read from the digital display of the device. TS was calculated by dividing the maximum force to rupture $(\mathrm{F})$ and the cross-section area of the membrane (A). The cross-section area (A) was obtained by multiplying the width and the average thickness of the membrane strips. TS was calculated using the formula given by $[26,27]$ :

$$
T S=\frac{F}{A}\left(\mathrm{~N} / \mathrm{m}^{2}\right)
$$

Where, $\mathrm{F}=$ maximum force to rapture the membrane $(\mathrm{N})$ $A=$ cross-sectional area of the membrane $\left(\mathrm{m}^{2}\right)$

ii. Elongation at break (EAB)

Elongation at break was calculated by dividing change in length of the membrane strips when the rupture occurred by the original length of the membrane strips before loading. This was calculated using the formula given $[27,25]$ :

$$
E A B=\frac{\Delta L}{L_{1}} \times 100
$$

Where $\Delta L=\mathrm{L}_{2}-\mathrm{L}_{1}$

$\mathrm{L}_{1}=$ original length (mm)

$\mathrm{L}_{2}=$ final length after rupture of the bio-polymer ( $\left.\mathrm{mm}\right)$

iii.Puncture test

Puncture test was conducted to determine force required to puncture the membrane. This was carried out using the manual mechanical testing machine. The puncture test was conduction using method described by [25]. Samples with diameters of $40 \mathrm{~mm}$ were fixed on the hollow plate of $20 \mathrm{~mm}$ internal dimeter using silicon gum. A cylindrical probe of 3 $\mathrm{mm}$ diameter attached to digital force gauge of the testing machine was moved perpendicularly to the membrane surface until the probe passed through the film. At rupture point, deformation force was measured.

\subsubsection{Modelling and Optimization of the Membrane Quality Parameters}

a. Modelling of the membrane quality parameters (responses)

Modelling and optimization of the membrane quality parameters were carried out using response surface method on design expert (version 11.1.0) software package. For the 7 blend compositions and 3 plasticizer compositions as factors $(7 \times 3$ factorial design), a total 21 trial formulations were generated as independent variables. Membrane thickness, membrane solubility (\%), Water vapor permeability $\left(\mathrm{g} \mathrm{H}_{2} \mathrm{O}\right.$ $\mathrm{mm} \mathrm{m}^{-2}$ day $\left.\mathrm{kPa}\right)$, Tensile stress $(\mathrm{MPa})$, Elongation at break $(\%)$, and Puncture strength $(\mathrm{kN})$ were evaluated as dependent variables (responses). The composition variables (factors) and their corresponding responses values (quality 
parameters) are reported in Table 2. The mean values of the investigated responses measured for all trial formulations in the $7 \times 3$ factorial design were fitted to get model equations. Best-fitting mathematical models were determined based on the comparison of statistical parameters such as adjusted multiple correlation coefficient (adjusted $-\mathrm{R}^{2}$ ), and predicted multiple correlation coefficient (predicted- $\mathrm{R}^{2}$ ).

b. Optimization of membrane formulations

Optimization of the membrane compositions were carried out based on the criteria of the film thickness, vapor permeability, film solubility, tensile strength, elongation at break and puncture strength. The blend and plasticizer compositions were set in the range of the lower and upper limit. Vapor permeability, film solubility and elongation at break criterion were given a weighting of 5 (highest) while other responses such as tensile stress, film thickness and puncture strength were given a weighting of 3 (moderate). This weighting was done based on the importance of each characteristic of the membrane as a need for food encapsulation, where the Vapor permeability, film solubility and elongation at break determine the ability of the membrane to protect the core against moisture during storage, enhance release rate of the core and enhance plasticity of the membrane respectively.

Table 2. Formulation variables and their corresponding experimental values.

\begin{tabular}{|c|c|c|c|c|c|c|c|}
\hline $\begin{array}{l}\text { Blend Compositions } \\
\text { Soy-protein: Cassava } \\
\text { Starch }(\%)\end{array}$ & $\begin{array}{l}\text { Plasticizer } \\
\text { compositions } \\
\text { Glycerol: } \\
\text { Sorbitol (\%) } \\
\end{array}$ & $\begin{array}{l}\text { Thickness } \\
\text { (mm) }\end{array}$ & $\begin{array}{l}\text { Water Vapour } \\
\text { Permeability (g } \\
\mathrm{H}_{2} \mathrm{O} \mathrm{mm} \mathrm{m}^{-2} \text { ) } \\
\text { day } \mathrm{kPa}\end{array}$ & $\begin{array}{l}\text { Film } \\
\text { Solubility (\%) }\end{array}$ & $\begin{array}{l}\text { Tensile Stress } \\
\text { (MPa) }\end{array}$ & $\begin{array}{l}\text { Elongation at } \\
\text { break }(\%)\end{array}$ & $\begin{array}{l}\text { Puncture } \\
\text { strength }(k N)\end{array}$ \\
\hline \multirow{3}{*}{ 100:0 } & P1 (100:0) & $0.19 \pm 0.01$ & $19.70 \pm 0.08$ & $25.00 \pm 0.01$ & $28.88 \pm 0.16$ & $17.86 \pm 0.20$ & $2.30 \pm 0.08$ \\
\hline & P2 (80:20) & $0.19 \pm 0.03$ & $16.47 \pm 0.04$ & $24.33 \pm 0.57$ & $31.50 \pm 0.15$ & $15.80 \pm 0.18$ & $2.47 \pm 0.02$ \\
\hline & P3 (60:40) & $0.20 \pm 0.01$ & $15.65 \pm 0.54$ & $24.44 \pm 0.13$ & $35.04 \pm 0.11$ & $14.26 \pm 0.31$ & $2.52 \pm 0.03$ \\
\hline \multirow{2}{*}{$90: 10$} & P1 (100:0) & $0.21 \pm 0.01$ & $17.67 \pm 0.07$ & $30.33 \pm 0.56$ & $25.37 \pm 0.18$ & $16.56 \pm 0.61$ & $2.37 \pm 0.06$ \\
\hline & P3 (60:40) & $0.22 \pm 0.01$ & $14.78 \pm 0.05$ & $29.36 \pm 0.32$ & $32.01 \pm 0.15$ & $13.42 \pm 0.20$ & $2.80 \pm 0.01$ \\
\hline \multirow{3}{*}{$80: 20$} & P1 (100:0) & $0.22 \pm 0.01$ & $17.54 \pm 0.03$ & $38.05 \pm 0.05$ & $22.66 \pm 0.19$ & $15.08 \pm 0.12$ & $2.37 \pm 0.03$ \\
\hline & P2 (80:20) & $0.23 \pm 0.01$ & $14.83 \pm 0.06$ & $36.98 \pm 0.03$ & $27.82 \pm 0.47$ & $13.79 \pm 0.19$ & $2.98 \pm 0.01$ \\
\hline & P3 (60:40) & $0.23 \pm 0.01$ & $13.36 \pm 0.05$ & $37.51 \pm 0.04$ & $30.68 \pm 0.36$ & $12.56 \pm 0.27$ & $2.88 \pm 0.02$ \\
\hline \multirow{3}{*}{$70: 30$} & P1 (100:0) & $0.23 \pm 0.01$ & $16.50 \pm 0.01$ & $43.50 \pm 0.02$ & $21.29 \pm 0.16$ & $14.61 \pm 0.77$ & $2.33 \pm 0.04$ \\
\hline & P2 (80:20) & $0.23 \pm 0.01$ & $14.67 \pm 0.03$ & $41.05 \pm 0.05$ & $25.83 \pm 0.17$ & $11.58 \pm 0.17$ & $2.99 \pm 0.02$ \\
\hline & P3 (60:40) & $0.24 \pm 0.01$ & $13.66 \pm 0.04$ & $41.51 \pm 0.04$ & $28.21 \pm 0.18$ & $10.76 \pm 0.36$ & $3.02 \pm 0.03$ \\
\hline \multirow[t]{2}{*}{$60: 40$} & P2 (80:20) & $0.25 \pm 0.01$ & $14.52 \pm 0.03$ & $51.37 \pm 0.56$ & $25.34 \pm 0.27$ & $9.66 \pm 0.38$ & $2.87 \pm 0.02$ \\
\hline & P3 (60:40) & $0.25 \pm 0.01$ & $13.40 \pm 0.06$ & $51.47 \pm 0.04$ & $27.73 \pm 0.30$ & $8.69 \pm 0.28$ & $2.90 \pm 0.01$ \\
\hline \multirow{3}{*}{$50: 50$} & P1 (100:0) & $0.26 \pm 0.01$ & $15.11 \pm 0.03$ & $51.39 \pm 0.14$ & $20.72 \pm 0.34$ & $11.89 \pm 0.07$ & $1.97 \pm 0.01$ \\
\hline & P2 (80:20) & $0.27 \pm 0.01$ & $13.78 \pm 0.08$ & $50.49 \pm 0.08$ & $24.89 \pm 0.73$ & $8.96 \pm 0.08$ & $2.43 \pm 0.01$ \\
\hline & P3 $(60: 40)$ & $0.28 \pm 0.01$ & $13.06 \pm 0.07$ & $50.55 \pm 0.07$ & $26.91 \pm 0.98$ & $7.72 \pm 0.17$ & $2.52 \pm 0.02$ \\
\hline \multirow{3}{*}{$0: 100$} & P1 (100:0) & $0.21 \pm 0.01$ & $18.07 \pm 0.13$ & $82.49 \pm 0.05$ & $11.55 \pm 0.04$ & $10.30 \pm 0.48$ & $1.79 \pm 0.01$ \\
\hline & P2 (80:20) & $0.20 \pm 0.01$ & $17.11 \pm 0.02$ & $81.13 \pm 0.18$ & $13.36 \pm 0.44$ & $7.56 \pm 0.06$ & $1.84 \pm 0.02$ \\
\hline & P3 $(60: 40)$ & $0.21 \pm 0.01$ & $16.23 \pm 0.05$ & $80.46 \pm 0.05$ & $16.12 \pm 0.11$ & $7.93 \pm 1.65$ & $1.92 \pm 0.01$ \\
\hline
\end{tabular}

Mean and standard deviation of triplicate determination for the membrane quality parameters

\section{Results and Discussion}

\subsection{Summary of the Model Statistics}

Table 3 shows model summaries for measured quality parameter of the membranes

Table 3. Model summary for measured quality parameters of the membranes.

\begin{tabular}{|c|c|c|c|}
\hline Response & Model & Adjusted R $\mathbf{R}^{2}(\%)$ & Predicted $\mathbf{R}^{2}(\%)$ \\
\hline \multirow{3}{*}{ Film Thickness } & Linear & 0.1552 & -0.0759 \\
\hline & $2 \mathrm{~F}$ & 0.1060 & -0.3285 \\
\hline & Quadratic & 0.5627 & 0.3481 \\
\hline \multirow{3}{*}{ Film Solubility } & Linear & 0.8049 & 0.8527 \\
\hline & $2 \mathrm{~F}$ & 0.7474 & 0.8441 \\
\hline & Quadratic & 0.8226 & 0.8899 \\
\hline \multirow{2}{*}{ Water Vapor Permeability } & Linear & 0.2999 & 0.4782 \\
\hline & Quadratic & 0.7209 & 0.8176 \\
\hline \multirow{3}{*}{ Tensile Stress } & Linear & 0.7630 & 0.8167 \\
\hline & $2 \mathrm{~F}$ & 0.7065 & 0.8073 \\
\hline & Quadratic & 0.7278 & 0.8370 \\
\hline \multirow{3}{*}{ Elongation at break } & Linear & 0.9444 & 0.9541 \\
\hline & $2 \mathrm{~F}$ & 0.9339 & 0.9515 \\
\hline & Quadratic & 0.9461 & 0.9660 \\
\hline
\end{tabular}




\begin{tabular}{llll}
\hline Response & Model & Adjusted R $\mathbf{~}^{\mathbf{( \% )}}$ & Predicted R $^{\mathbf{2}} \mathbf{( \% )}$ \\
\hline \multirow{3}{*}{ Puncture strength } & Linear & 0.2821 & 0.4188 \\
& 2F & 0.1006 & 0.3853 \\
& Quadratic & 0.7433 & 0.8724 \\
\hline
\end{tabular}

From results table 3, considering the highest values of adjusted $\mathrm{R}^{2}$ and predicted $\mathrm{R}^{2}$, it can be observed that the film thickness, film solubility, vapor barrier, elongation at break and puncture strength were fitted best into quadratic models, while tensile stress was best fitted into linear model.

a. Modelling of the membrane quality parameters

Table 4 shows the statistical analysis from modelling of the membrane quality parameters.

Table 4. Statistical analysis from the modelling of the membrane quality parameters.

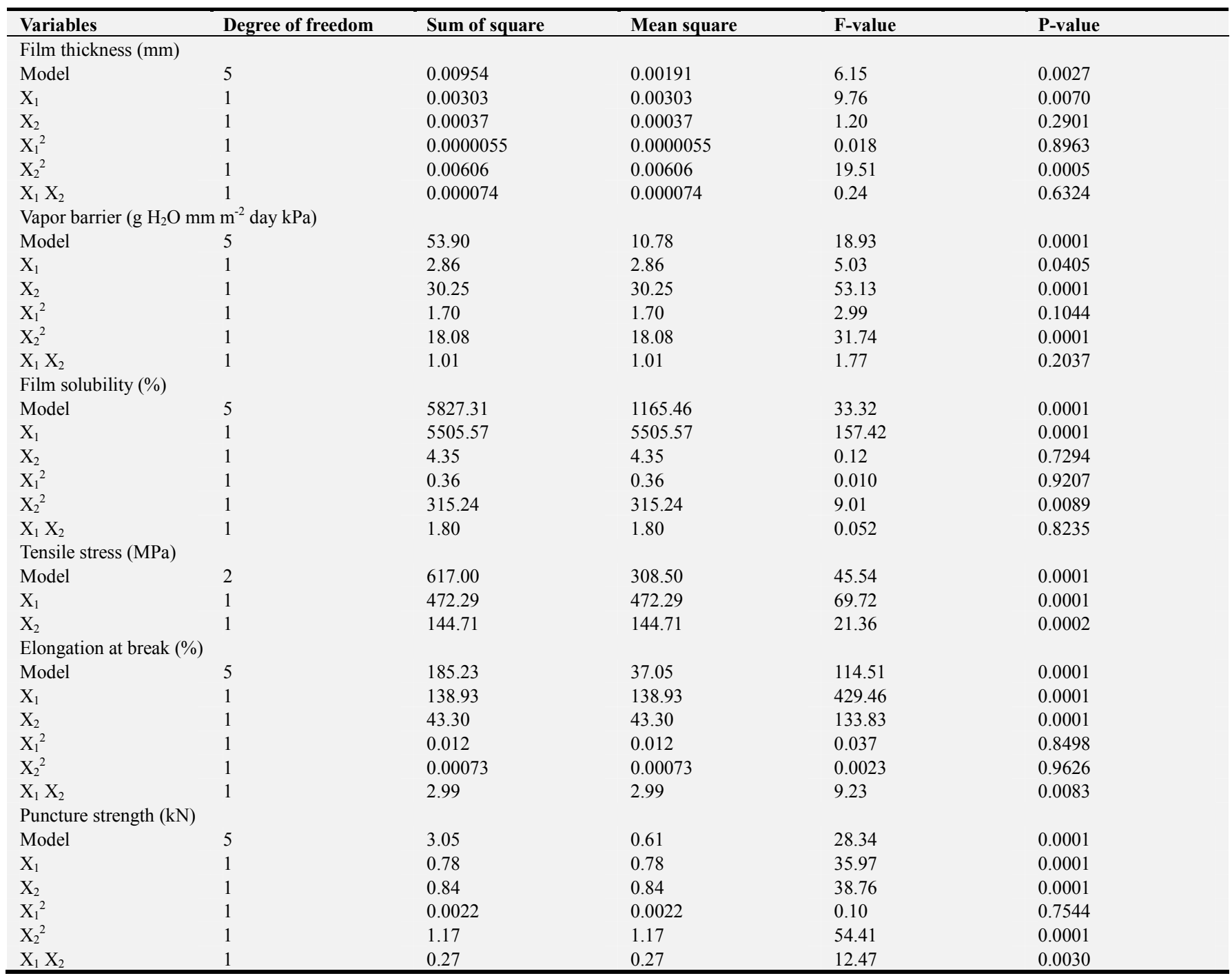

\section{b. Membrane thickness}

Films thickness is an important characteristic in determining the feasibility of edible films as packaging materials for food products since the thickness of the films affects other characteristics of the films, such as tensile strength, elongation, and water vapor permeability [29, 27]. It can be observed from results table 4 that the quadratic model shows $\mathrm{p}$ value 0.0027 , implying that the chance of the model error is less than 5\%. This indicates that the quadratic model is suitable for the film thickness. The actual quadratic equation of the film thickness response is as follow:

$$
\mathrm{Y}=0.046 \mathrm{X}_{1}+0.00398 \mathrm{X}_{2}{ }^{2}+0.393
$$

Description: $\mathrm{Y}=$ Film thickness $(\mathrm{mm})$

$\mathrm{X}_{1}=$ Blend compositions $(\%)$

$\mathrm{X}_{2}=$ Plasticizer compositions $(\%)$

From the statistical analysis in table 4 , it can be observed that the factors which significantly $(p<0.05)$ affect the film thickness response were the blend composition $\left(\mathrm{X}_{1}\right)$, and the square of the plasticizer composition $\left(\mathrm{X}_{2}^{2}\right)$, while the plasticizer compositions $\left(\mathrm{X}_{2}\right)$, square of the blend compositions $\left(\mathrm{X}_{1}^{2}\right)$ and the interaction between the treatments $\left(\mathrm{X}_{1} \mathrm{X}_{2}\right)$ did not significantly $(\mathrm{p}>0.05)$ affect the film thickness response. Positive values of coefficients $X_{1}$ in the equation (5) showed that increasing the percentage of 
cassava starch in the soy-protein isolate blend led to increase in the film thickness. Increasing the thickness due to the effect of an increase base material composition had previously been reported by other researchers [30, 21]. The response surface plot of the blend and plasticizer effects against the film thickness is shown in figure 7.

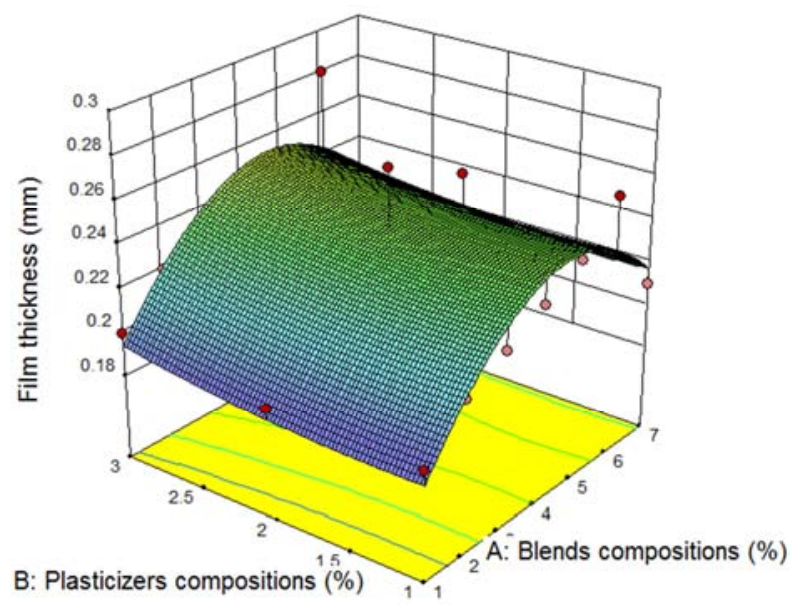

Figure 7. Effect of blend and plasticizer compositions on film thickness.

It can be observed from the figure that the film thickness increases in a quadratic curve from $\mathrm{B}_{1}(100 \%$ soy-protein isolate based membrane) to $\mathrm{B}_{6}$ (composite of $50 \%$ soyprotein isolate and $50 \%$ cassava starch based membrane) and then sharply decreases to $\mathrm{B}_{7}(100 \%$ cassava starch). Cassava starch based membrane ( $100 \%$ cassava starch) is observed to be higher in thickness than that of the soy-protein isolate based membrane (100\% soy-protein isolate). Observation from this figures also showed that mixture of soy-protein isolate and cassava starch as a composite led to improved thickness of the membrane. This is to further confirm that base material compositions affect the film thickness [30]. For the effect of blend compositions on the membrane thickness, it can be observed from the figure that the percentage composition of glycerol and sorbitol did not affect the film thickness.

c. Vapor permeability of the membranes

Determination of vapor permeability of the membrane is very important in this research since the membrane is intended for microencapsulation of carrot powders. Higher vapor permeability of the membrane can enhance the rate of carotene oxidation and increase the rate of micro-organism growth [31] both of which are main factors that can affect shelf life of the carrot micro-particles. It can be observed from results table 4 that the quadratic model shows $p$ value 0.0001 for the membrane vapor permeability, implying that the chance of the model error is less than $5 \%$. This indicates that the quadratic model is suitable for the vapor permeability of the membrane. The actual quadratic equation of the solubility response is as follow:

$$
Y=14.24-0.55 X_{1}-1.47 X_{2}+0.46 X_{2}^{2}
$$

$\left(\mathrm{X}_{1}^{2}\right.$ and $\mathrm{X}_{1} \mathrm{X}_{2}$ not significant $)$
Description: $\mathrm{Y}=$ vapor barrier $\left(\mathrm{g} \mathrm{H}_{2} \mathrm{O} \mathrm{mm} \mathrm{m}^{-2}\right.$ day $\left.\mathrm{kPa}\right)$

$\mathrm{X}_{1}=$ blend compositions $(\%)$

$\mathrm{X}_{2}=$ plasticizer compositions $(\%)$

From the statistical analysis in table 4 , it can be observed that the factors which significantly $(p<0.05)$ affect the vapor permeability response were the blend composition $\left(\mathrm{X}_{1}\right)$, the plasticizer compositions $\left(\mathrm{X}_{2}\right)$, and the square of the plasticizer composition $\left(\mathrm{X}_{2}^{2}\right)$, while square of the blend compositions $\left(\mathrm{X}_{1}{ }^{2}\right)$ and the interaction effect between the treatments $\left(\mathrm{X}_{1} \mathrm{X}_{2}\right)$ did not significantly $(\mathrm{p}>0.05)$ affect the vapour permeability response. Negative values of coefficients $\mathrm{X}_{1}$ and $\mathrm{X}_{2}$ in the equation (6) showed that the addition of cassava starch to soy-protein isolate (blends) and the addition of sorbitol to glycerol (plasticizer) significantly reduced the membrane vapor permeability. This implies that interactive effect of blend compositions (soy-protein isolate and cassava starch combinations) and plasticizer compositions (glycerol and sorbitol combinations) led to decrease in vapor permeability of the membrane. [23] reported that the combination of cassava starch and soy-protein concentrate blend resulted into lower vapor permeability. [32] also reported the decrease in vapor permeability when they evaluated the effect of glycerol and sorbitol on cassava starch biodegradable films. The response surface plot of the blend and plasticizer effects against the film solubility is shown in figure 8 .

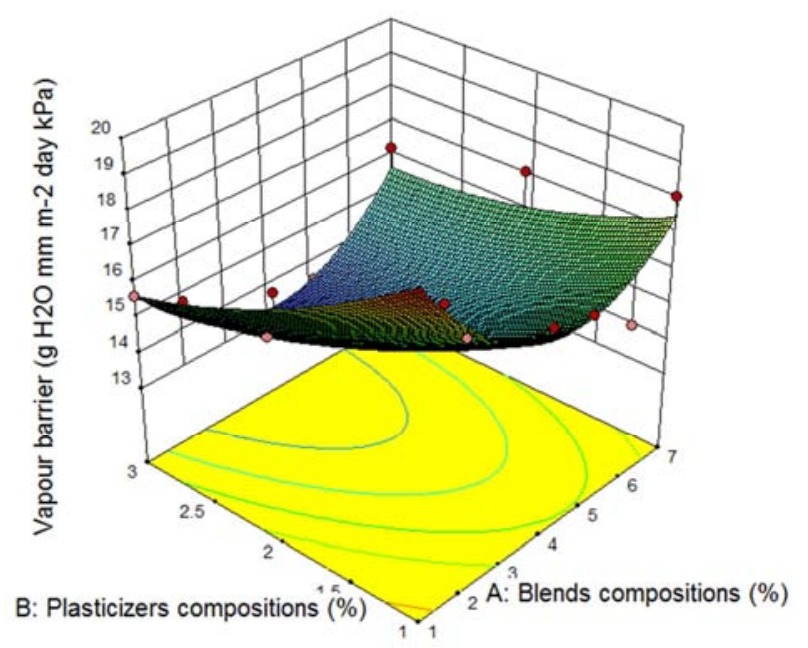

Figure 8. Effect of blend and plasticizer compositions on vapour permeability.

It can be observed from the figure that the vapor permeability of the membranes tends to decrease in a quadratic curve up to the middle as the percentage of cassava starch increases in the soy-protein isolate blend but increase above the middle as the percentage of soy-protein reduces in the cassava starch based membrane. The vapor permeability steadily decreases from $\mathrm{B}_{1}(100 \%$ soy-protein isolate $)$ through $\mathrm{B}_{2} \quad(90 \%$ soy-protein isolate and $10 \%$ cassava starch), $\mathrm{B}_{3}(80 \%$ soy-protein isolate and $20 \%$ cassava starch), up to $\mathrm{B}_{4}(70 \%$ soy-protein isolate and $30 \%$ cassava starch) then increase sharply to $\mathrm{B}_{5}(60 \%$ soy-protein isolate and $40 \%$ cassava starch), $\mathrm{B}_{6}(50 \%$ soy-protein isolate and $50 \%$ cassava 
starch) up to $\mathrm{B}_{7}(100 \%$ cassava starch). This implies that cassava starch plays a key role in lowering the vapor permeability of the membrane. For plasticizer compositions, the vapor permeability of membrane decreases sharply as the percentage of sorbitol added to glycerol increases. The membrane vapor permeability decreases steadily from $\mathrm{P}_{1}$ ( $100 \%$ glycerol), to $\mathrm{P}_{2}(80 \%$ glycerol and $20 \%$ sorbitol) and was the least at $\mathrm{P}_{3}(60 \%$ glycerol and $40 \%$ sorbitol $)$.

d. Membrane solubility

Determination of the membranes solubility before the product utilization might be crucial as in encapsulation of foods or additives since this affects the release rate of the core $[33,34]$. It can be observed from results table 4 that the quadratic model shows $\mathrm{p}$ value 0.0001 , implying that the chance of the model error is less than $5 \%$. This indicates that the quadratic model is suitable for the solubility of the membrane. The actual quadratic equation of the solubility response is as follow:

$$
\mathrm{Y}=24.29 \mathrm{X}_{1}+0.62 \mathrm{X}_{2}^{2}+40.50
$$

$\left(\mathrm{X}_{2}, \mathrm{X}_{1}{ }^{2}\right.$ and $\mathrm{X}_{1} \mathrm{X}_{2}$ not significant $)$

Description: $\mathrm{Y}=$ film solubility $(\%)$

$\mathrm{X}_{1}=$ blend compositions $(\%)$

$\mathrm{X}_{2}=$ plasticizer compositions $(\%)$

From the statistical analysis in table 4 , it can be observed that the factors which significantly $(p<0.05)$ affect the membrane solubility response were the blend composition $\left(\mathrm{X}_{1}\right)$, and the square of the plasticizer composition $\left(\mathrm{X}_{2}^{2}\right)$. While the plasticizer compositions $\left(\mathrm{X}_{2}\right)$, square of the blend compositions $\left(\mathrm{X}_{1}^{2}\right)$ and the interaction between the treatments $\left(\mathrm{X}_{1} \mathrm{X}_{2}\right)$ did not significantly $(\mathrm{p}>0.05)$ affect the membrane response. Positive values of coefficients $X_{1}$ in the equation (6) showed that increasing the percentage of cassava starch in the soy-protein isolate blend led to increase in the membrane solubility. Increasing the film solubility due to the effect of an increase in percentage of cassava starch added to soy-protein concentrate had also been reported by [23]. The response surface plot of the blend and plasticizer effects against the film solubility is shown in figure 9 .

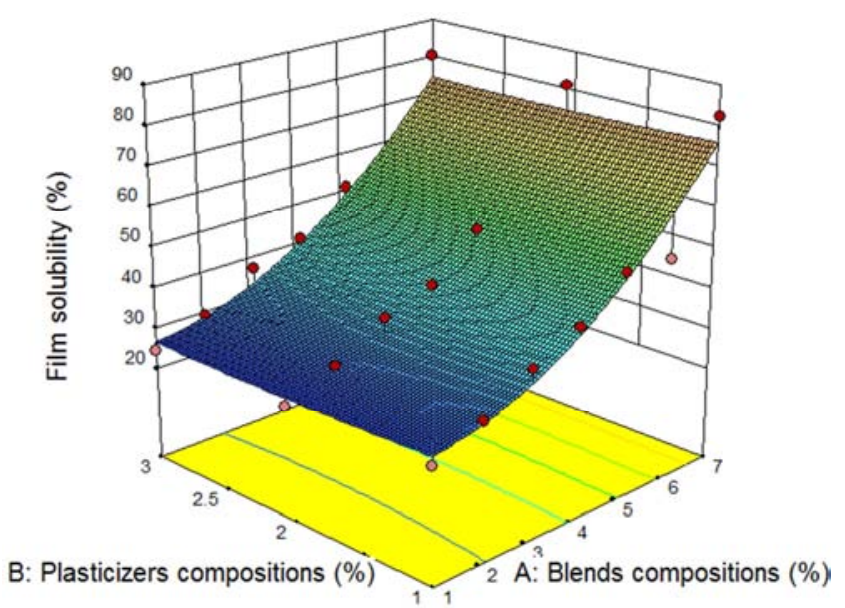

It can be observed from the figure that the sample code $\mathrm{B}_{7}(100 \%$ cassava starch based membrane $)$ had the highest solubility while that of the $\mathrm{B}_{1}(100 \%$ soy-protein isolate based membrane) had the least solubility. It can also be observed that the more the amount of cassava starch in soy-protein isolate blends, the higher the membrane solubility as it can be seen from the figure that $\mathrm{B}_{6}(50 \%$ soy-protein isolate and $50 \%$ cassava starch based membrane) is higher in terms of solubility than that of the $\mathrm{B}_{5}(60 \%$ soy-protein isolate and $40 \%$ cassava starch based membrane) and the results follow the same trend. For the effect of plasticizer compositions on the membrane solubility, it can be observed from the figure that the percentage composition of glycerol and sorbitol did not affect the film solubility.

e. Tensile stress of the membrane

Tensile stress expresses the maximum stress developed in a film during a tensile test; it offers a measure of integrity as well as heavy duty use potential for films [35]. High tensile stress is generally required for edible films, but this depends on the intended application of the films [34]. It can be observed from results table 4 that the linear model shows $\mathrm{p}$ value 0.0001 for the membrane tensile stress, implying that the chance of the model error is less than $5 \%$. This indicates that the linear model is suitable for the tensile stress of the membrane. The actual linear equation of the tensile stress response is as follow:

$$
\mathrm{Y}=3.21 \mathrm{X}_{2}-7.11 \mathrm{X}_{1}+25.09
$$

Description: $\mathrm{Y}=$ Tensile stress $(\mathrm{MPa})$

$\mathrm{X}_{1}=$ blend compositions $(\%)$

$\mathrm{X}_{2}=$ plasticizer compositions $(\%)$

From the statistical analysis in table 4 , it can be observed that both factors $\left(\mathrm{X}_{1}\right.$ and $\left.\mathrm{X}_{2}\right)$ significantly $(\mathrm{p}<$ 0.05 ) affect the tensile stress response. Negative value of coefficients $X_{1}$ in the equation (8) showed that increase in percentage of cassava starch added in soy-protein isolate blends decreased tensile stress of the membrane linearly. The decrease in tensile strength of soy-protein isolate based membranes because of cassava starch addition could be explained by the fact that the lower the protein content in film-forming solution, the lower the aggregation of protein that might have improved the film strength [36]. Positive value of coefficients $\mathrm{X}_{2}$ in the equation (8) implies that increase in percentage of sorbitol added in glycerol plasticizer increased the tensile stress of the membrane linearly. This increase could be attributed to the fact that addition of sorbitol which is of higher molecular weight and solid characteristics at room temperature affected the plasticizing effect of glycerol thereby making the membranes to be more stiff which consequently translate to higher strength of the film. [37]. The response surface plot of the blend and plasticizer effects against the film solubility is shown in figure 10 .

Figure 9. Effect of blend and plasticizer compositions on film solubility. 


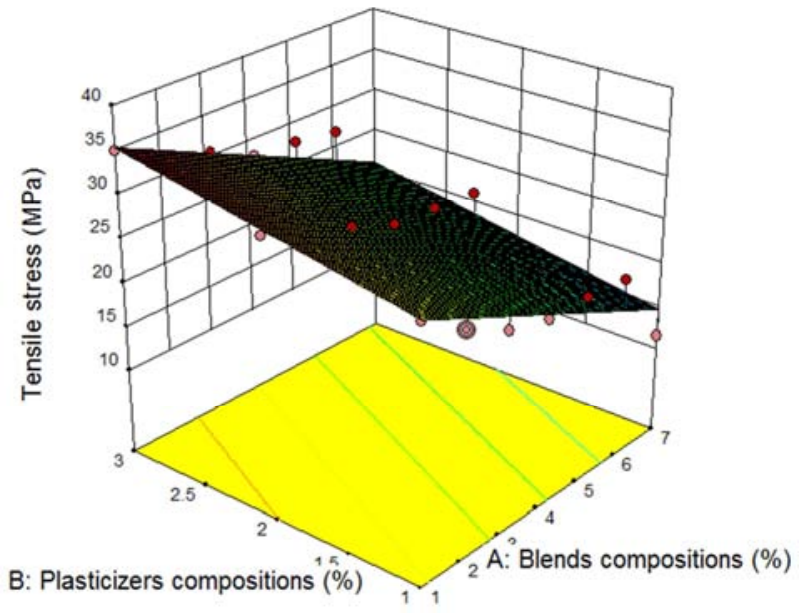

Figure 10. Effect of blend and plasticizer compositions on tensile stress.

It can be observed from the figure that the $100 \%$ soyprotein isolate based membrane $\left(\mathrm{B}_{1}\right)$ had the highest value of tensile stress followed by $\mathrm{B}_{2}$ (composite of $90 \%$ soy-protein isolate and $10 \%$ cassava starch) while that of $100 \%$ cassava starch based membrane $\left(\mathrm{B}_{7}\right)$ had the least value of tensile stress. This implies that addition of cassava starch to soyprotein isolate based membrane limits the strength of the membrane but compare with the cassava starch based membrane, composite of soy-protein isolate and cassava starch significantly resulted to higher values of tensile stress. Similarly, from the figure it can be observed that only glycerol plasticizer $\left(\mathrm{P}_{1}\right)$ resulted to the least value of tensile stress of the membrane followed by $\mathrm{P}_{2}$ (combination of $80 \%$ glycerol and $20 \%$ sorbitol) while $\mathrm{P}_{3}$ (combination of $60 \%$ glycerol and $40 \%$ sorbitol) had the highest tensile stress.

f. Elongation at break of the membrane

Elongation at break (EAB) is the ability of the films to extend before breaking. It describes the nature of the film plasticity. Plasticity is generally required for a film to maintain its integrity when applied to food products [29, 28]. It can be observed from results table 4 that the quadratic model shows $\mathrm{p}$ value 0.0001 for the membrane EAB, implying that the chance of the model error is less than $5 \%$. This indicates that the model is suitable for the $\mathrm{EAB}$ of the membrane. The actual equation of the $\mathrm{EAB}$ response is as follow:

$$
\mathrm{Y}=11.71-3.86 \mathrm{X}_{1}-1.76 \mathrm{X}_{2}-0.044 \mathrm{X}_{1} \mathrm{X}_{2}
$$

Description: $\mathrm{Y}=$ Elongation at break (\%)

$\mathrm{X}_{1}=$ blend compositions $(\%)$

$\mathrm{X}_{2}=$ plasticizer compositions $(\%)$

From the statistical analysis in table 4 , it can be observed that the factors which significantly $(\mathrm{p}<0.05)$ affect the EAB response were $\mathrm{X}_{1}$ (blend composition), $\mathrm{X}_{2}$ (plasticizer composition) and interactive effect of $\mathrm{X}_{1} \mathrm{X}_{2}$ (blend compositions and plasticizer composition) while square of blend composition $\mathrm{X}_{1}{ }^{2}$ and square of plasticizer composition $\mathrm{X}_{2}{ }^{2}$ did not significantly $(p>0.050$ affect the EAB. Negative value of coefficients $X_{1}$ in the equation (9) shows that increase in percentage of cassava starch added in soy-protein isolate based membrane decreases plasticity $(\mathrm{EAB})$ of the membrane linearly. [38] had previously reported that addition of starch to protein based film significantly reduce its flexibility. Negative value of coefficients $X_{2}$ in the equation (9) indicates that increase in percentage of sorbitol added in glycerol decreases plasticity (EAB) of the membrane. [37] reported a decrease in elongation at break of the film as a result of interaction between sorbitol and glycerol. Negative value of coefficients $X_{1} X_{2}$ in the equation (9) indicates antagonistic effect on the elongation at break of the membrane [21]. The response surface plot of the blend and plasticizer effects against the film solubility is shown in figure 11.

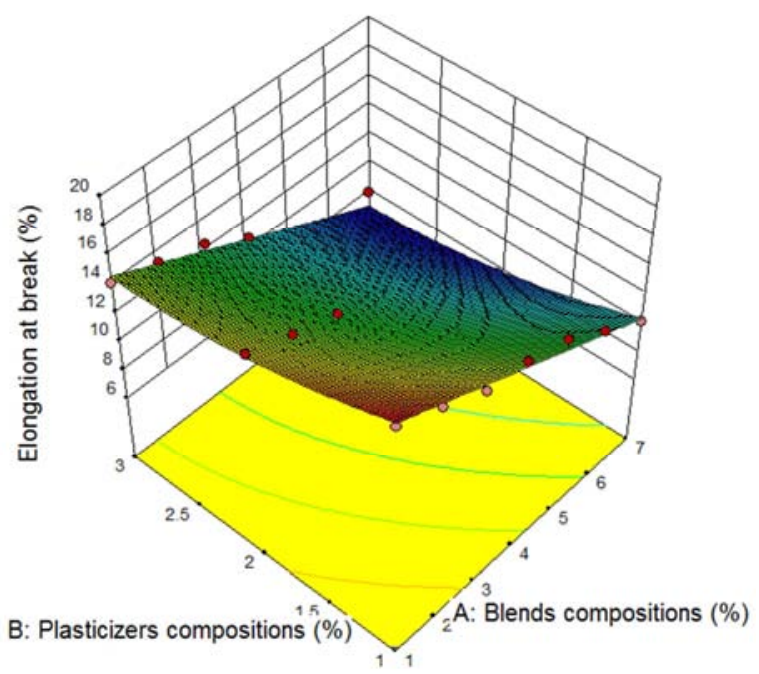

Figure 11. Effect of blend and plasticizer compositions on elongation at break.

It can be observed from the figure that the $100 \%$ soy-protein isolate based membrane $\left(\mathrm{B}_{1}\right)$ had the highest EAB followed by $\mathrm{B}_{2}$ (composite of $90 \%$ soy-protein isolate and $10 \%$ cassava starch) while that of $100 \%$ cassava starch based membrane $\left(\mathrm{B}_{7}\right)$ had the least $\mathrm{EAB}$ value. This implies that addition of cassava starch to soy-protein isolate based membrane limits the EAB property of the membrane but compare with the cassava starch based membrane, composites of soy-protein isolate and cassava starch significantly resulted to improved elongation at break of the film. Similarly, from figure 11 it can be observed that $100 \%$ glycerol plasticizer $\left(\mathrm{P}_{1}\right)$ resulted to the highest $\mathrm{EAB}$ while $\mathrm{P}_{2}$ (combination of $80 \%$ glycerol and $20 \%$ sorbitol) and $\mathrm{P}_{3}$ (combination of $60 \%$ glycerol and $40 \%$ sorbitol) were similar in EAB and both were lower than that of $100 \%$ glycerol plasticized membrane.

g. Puncture strength of the membrane

Puncture strength of the membrane measured the force required to push a puncture and probe into a food or food products. It can be observed from results table 4 that the quadratic model shows $\mathrm{p}$ value 0.0001 for the membrane puncture strength, implying that the chance of the model error is less than $5 \%$. This indicates that the quadratic model is suitable for the puncture strength of the membrane. The actual equation of the puncture strength response is as follow: 


$$
\mathrm{Y}=2.92-0.29 \mathrm{X}_{1}+0.24 \mathrm{X}_{2}+0.019 \mathrm{X}_{1} \mathrm{X}_{2}-0.24 \mathrm{X}_{2}^{2}(10)
$$

Description: $\mathrm{Y}=$ Puncture strength $(\mathrm{kN})$

$\mathrm{X}_{1}=$ blend compositions $(\%)$

$\mathrm{X}_{2}=$ plasticizer compositions $(\%)$

From the statistical analysis in table 4 , it can be observed that the factors which significantly $(\mathrm{p}<0.05)$ affect the $\mathrm{EAB}$ response were $\mathrm{X}_{1}$ (blend composition), $\mathrm{X}_{2}$ (plasticizer composition), interactive effect of $\mathrm{X}_{1} \mathrm{X}_{2}$ (blend compositions and plasticizer composition) and square of plasticizer composition $\mathrm{X}_{2}^{2}$ while square of blend composition $\mathrm{X}_{1}^{2}$ did not significantly $(p>0.050)$ affect the elongation at break. The response surface plot of the blend and plasticizer effects against the puncture strength is shown in figure 12 .

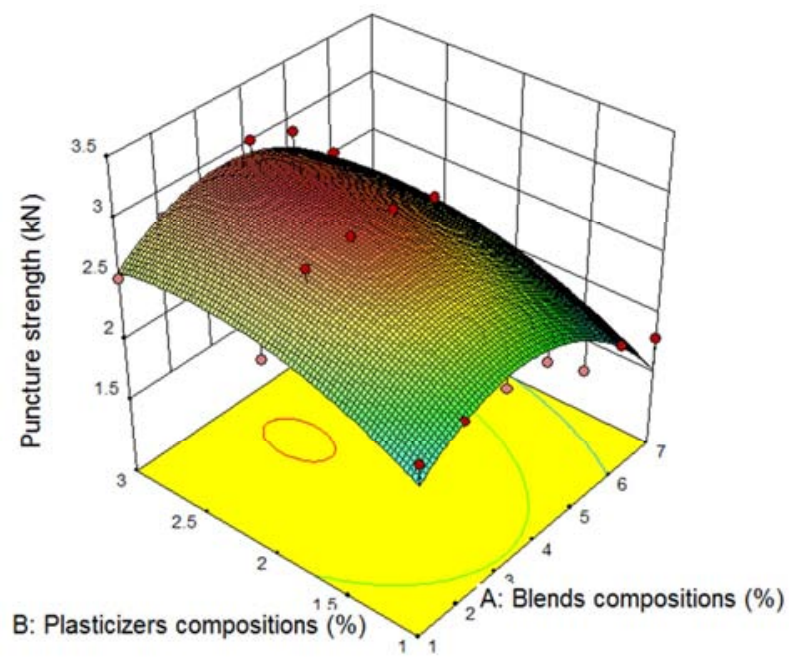

Figure 12. Effect of blend and plasticizer compositions on puncture strength.

It can be observed from the figure that the membrane puncture strength tends to increase in a quadratic curve from $\mathrm{B}_{1}\left(100 \%\right.$ cassava starch) to the $\mathrm{B}_{4}$ (composite of $70 \%$ soyprotein isolate and $30 \%$ cassava starch based membrane) and then steadily decrease to $\mathrm{B}_{7}(100 \%$ cassava starch $)$. Observation from this figure showed that combining soyprotein isolate with cassava starch as a composite blend to develop a membrane led to improved puncture strength. This could be attributed to strong interaction between protein and starch that led to the formation of a dense matrix resulting in improved puncture strength [35]. Similarly, from the figure it can be observed that the puncture strength tends to increase in a quadratic curve from $\mathrm{P}_{1}(100 \%$ glycerol $)$ up to $\mathrm{P}_{3}$ (composite of $60 \%$ glycerol and $40 \%$ sorbitol based plasticizer). The higher the percentage of sorbitol in the composite of glycerol and sorbitol based plasticizer, the higher the membrane puncture strength meaning that sorbitol plays a key role in the improvement of the puncture strength.

\subsection{Optimization of the Membrane}

Simulation program Design Expert (version 11.1.0) generates an optimum solution formulation for the manufacture of the composite membrane which is $\mathrm{B}_{4}(70 \%$ soy-protein isolate and $30 \%$ cassava starch) and $\mathrm{P}_{2}(80 \%$ glycerol and $20 \%$ sorbitol $)$ with the desirability value of 0.039 . This optimum formulation provides responses for the membrane parameters such as membrane thickness of $0.24 \mathrm{~mm}$, vapor permeability of $16.06 \mathrm{~g}$ $\mathrm{H}_{2} \mathrm{O} \mathrm{mm} \mathrm{m}{ }^{-2}$ day $\mathrm{kPa}$, membrane solubility of $45.95 \%$, tensile stress of $20.71 \mathrm{MPa}$, elongation at break of $13.65 \%$ and puncture strength of $2.37 \mathrm{kN}$.

\section{Conclusion}

Soy-protein isolate and cassava starch based Bio-polymer (Polymeric membrane) had been successfully developed and its quality parameters had been modelled and optimized. The membrane thickness, membrane solubility, vapor barrier, elongation at break and puncture strength were fitted best into quadratic models, while tensile stress was best fitted into linear model. The Blend compositions (soy-protein isolate: cassava starch) of 70:30 and Plasticizers compositions (glycerol: sorbitol) of 80:20 were found to be the optimum compositions in the development of the composite membrane with a desirability value of 0.039 . Quality parameters at these optimum compositions are membrane thickness of $0.24 \mathrm{~mm}$, vapor permeability of $16.06 \mathrm{~g} \mathrm{H}_{2} \mathrm{O} \mathrm{mm} \mathrm{m} \mathrm{mm}^{-2}$ day $\mathrm{kPa}$, membrane solubility of $45.95 \%$, tensile stress of $20.71 \mathrm{MPa}$, elongation at break of $13.65 \%$ and puncture strength of 2.37 $\mathrm{kN}$.

\section{Acknowledgements}

Kamaldeen Oladimeji Salaudeen is grateful to Nigerian Stored Products Research Institute (NSPR) and CEFTER for the award of postgraduate fellowship.

\section{References}

[1] Desai K. G. H. \& Park H. J., (2005) Recent Developments in Microencapsulation of Food Ingredients. Drying Technol., 23: 1361-94.

[2] Fang Z. \& Bhandari B. (2009). Encapsulation of polyphenols: A Review. Trends Food Sci Technol 21: 510-23.

[3] Vos P., Faas M. M., Spasojevic M. \& Sikkema J. (2010). Review: Encapsulation for Preservation of Functionality and Targeted Delivery of Bioactive Food Components. Int Dairy Journal, 20: 292-302.

[4] Seydim A. C., and Sarikus G., (2006). Antimicrobial Activity of Whey Protein Based Edible Films Incorporated with Oregano, Rosemary and Garlic Essential Oils. Food Research International, 39, 639-644. www.sciencedirect.com

[5] Alicia H., Fre'de'ric D., Laurent B., Thomas K., and Andrée V., (2008). Protection of Active Aroma Compound against Moisture and Oxygen by Encapsulation in Biopolymeric Emulsion-Based Edible Films. Biomacromolecules, 3 (9) 1058-1063. www.sciencedirect.com

[6] Alicia H., Maria-José F., Frédéric D., Cécile D., and Andrée V., (2009). Interface and Aroma Barrier Properties of IotaCarrageenan Emulsion-Based Films Used for Encapsulation of Active Food Compounds. Journal of Food Engineering, 93, $80-88$. 
[7] Helena C. F. C., Renata V. T., Carlos R. F. G., and Míriam D. H., (2013). Encapsulation Efficiency and Oxidative Stability of Flaxseed Oil Microencapsulated by Spray Drying Using Different Combinations of Wall Materials. Journal of Food Engineering, $\quad 11 \quad$ (5), 443-451. www.elsevier.com/locate/jfoodeng

[8] Claudia P., Coronel-Aguilera M., and Fernanda San M., (2014). Encapsulation of Spray Dried B-Carotene Emulsion by Fluidized Bed Coating Technology. Food Science and Technology, 1-7. www.elsevier.com/locate/lwt=99

[9] Regalado, C., Perez-Perez, C., Lara-Cortes, E. \& GarciaAlmendarez, B. (2006). Whey Protein Based Edible Food Packaging Films and Coatings. Advances in Agricultural and Food Biotechnology, Pp. 237-261. Kerala, India: Research Signpost.

[10] Vásconez, M. B., Flores, S. K., Campos, C. A., Alvarado, J. and Gerschenson, L. N. 2009. Antimicrobial activity and physical properties of chitosan-tapioca starch based edible films and coatings. Food Research International 42: 762-769.

[11] Cutter, C. N. 2006. Opportunities for Bio-based Packaging Technologies to Improve the Quality and Safety of Fresh and Further Processed Muscle Foods, Meat Science, 74: 131-142.

[12] Elsabee, M. Z. and Abdou, E. S. 2013. Chitosan Based Edible Films and Coatings: A Review Materials, Science and Engineering, 33: 1819-1841.

[13] Han, J. H. 2000. Antimicrobial food Packaging. Food Technology (54) 56-65.

[14] Malakar J, Nayak A. K., Pal D. and Jana P. (2013). Potato starch - blended alginate beads for prolonged release of tolbutamide: Development by statistical optimization and in vitro characterization. Asian Journal of Pharmaceutics, www.asiapharmaceutics.info

[15] Ozdemir, M. and Floros, J. D. 2008. Optimization of edible whey protein films containing preservatives for water vapor permeability, water solubility and sensory characteristics. Journal of Food Engineering, 86 (2): 215-224.

[16] Chillo, S., Flores, S., Mastromatteo, M., Conte, A., Gerschenson, L. and Del Nobile, M. A. 2008. Influence of glycerol and chitosan on tapioca starch-based edible film properties. Journal of Food Engineering 88 (2): 159-168.

[17] Arismendi, C., Chillo, S., Conte, A., Del Nobile, M. A., Flores, S. and Gerschenson, L. N. 2013. Optimization of physical properties of xanthan gum/tapioca starch edible matrices containing potassium sorbate and evaluation of its antimicrobial effectiveness. LWT-Food Science and Technology 53 (1): 290-296.

[18] Maran, J. P., Sivakumar, V., Sridhar, R. and Immanuel, V. P. 2013a. Development of model for mechanical properties of tapioca starch based edible films. Industrial Crops and Products 42 (1): 159-168.

[19] Maran, J. P., Sivakumar, V., Thirugnanasambandham, K. and Sridhar, R. 2013b. Response surface modeling and analysis of barrier and optical properties of maize starch edible films. International Journal of Biological Macromolecules 60: 412421.

[20] Azevedo, A. N., Buarque, P. R., Cruz, E. M. O., Blank, A. F., Alves, P. B., Nunes, M. L. and Santana, L. C. L. A. 2014. Response surface methodology for optimisation of edible chitosan coating formulations incorporating essential oil against several foodborne pathogenic bacteria. Food Control 43: $1-9$.

[21] Arham R., Salengke S., Metusalach M. and Mulyati, M. T. (2018). Optimization of agar and glycerol concentration in the manufacture of edible film. International Food Research Journal 25 (5): Pp 1845-1851. http://www.ifrj.upm.edu.my

[22] Ihekoronye, A. I. and Ngoddy, P. O. (1985). Integrated Food Science and Technology for the Tropics, Pp. 252-253. London: MacMillian Publishers.

[23] Chinma C. E, Ariahu C. C. and Abu, O. J. (2012). Development and Characterization of Cassava Starch and Soy Protein Concentrate Based Edible Films. International Journal of Food Science and Technology, 2012, 47, 383-389.

[24] Phan-The, D., Debeaufort, F., Voilley, A. \& Luu, D. (2009). Biopolymer Interactions Affect the Functional Properties of Edible Films Based on Agar, Cassava Starch and Arabinoxylan Blends. Journal of Food Engineering, 90, 548558.

[25] Sharma, N., Khatkar, B. S., Kaushik, R., Sharma, P. and Sharma, R. (2017). Isolation and development of wheat based gluten edible film and its physicochemical properties. International Food Research Journal 24 (1): 94-101, http://www.ifrj.upm.edu.my

[26] Ahmad, M., Benjakul, S., Prodpran, T. and Agustini, T. W. 2012. Physico-mechanical and antimicrobial properties of gelatin film from the skin of unicorn leather jacket incorporated with essential oils. Food Hydrocolloids 28: 189199.

[27] Arham R., Mulyati, M. T., Metusalach, M. and Salengke, S. (2016). Physical and mechanical properties of agar based edible film with glycerol plasticizer. International Food

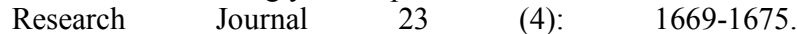
http://www.ifrj.upm.edu.my

[28] Borges, J. A., Romani, V. P., Cortez-Vega, W. R. and Martins, V. G. (2015). Influence of different starch sources and plasticizers on properties of biodegradable films. International Food Research Journal 22 (6): Pp 2346-2351.

[29] Galus, S. and Lenart, A. (2013). Development and characterization of composite edible films based on sodium alginate and pectin. Journal of Food Engineering 115: 459-465.

[30] Bhuvaneshwari, S., Sruthi, D., Sivasubramanian, V., Kalyani, N. and Sugunabai, J. 2011. Development and characterization of chitosan film. International Journal of Engineering Research and Applications 1 (2): Pp 292- 299.

[31] Akbari, Z., Ghomashchi, T. \& Moghadam, S. (2007). Improvement in Food Packaging Industry with Biobased Nanocomposites. International Journal of Food Engineering, 3 (4): 3 .

[32] Muhammed L. S., Salit M. S., Mohammad J, Mohamad R. I., and Japar S., (2015). Effect of Plasticizer Type and Concentration on Tensile, Thermal and Barrier Properties of Biodegradable Films Based on Sugar Palm (Arenga pinnata) Starch. Polymers, 7, 1106-1124; www.mdpi.com/journal/polymers.

[33] Bertuzzi, M. A., M. Armada, M. \& Gottifredi, J. C. (2007). Physicochemical Characterization of Starch Based Films. Journal of Food Engineering, 82, 17-25. 
[34] Bourtoom, T., Chinnan, M. S., Jantawat, P. \& Sanguandekul, R. (2006). Effect of Selected Parameters on The Properties of Edible Film from Water-Soluble Fish Proteins in Surimi Wash-Water. Lebensmittel-Wissenschaft und-Technologie, 39, 406-419.

[35] Gounga, M. E., XU, S. Y. and Wang, Z. (2007). Whey protein isolate-based edible films as affected by protein concentration, glycerol ratio and pullulan addition in film formation. J. Food Eng. 83 (4), 521-530.

[36] Gounga, M. E., Xu, S. \& Wang, Z. (2010). Film forming mechanism and mechanical and thermal properties of whey protein isolate-based edible films as affected by protein concentration, glycerol ratio and pullulan content. Journal of Food Biochemistry, 33, 501-519.

[37] Jeannine B. L., N'ivea M. V., Rodolfo M. C. Dos S, Ana M, Onica Q. B., and Sobrala J. A. (2015). Mechanical properties of cassava starch films as affected by different plasticizers and different relative humidity conditions. International Journal of Food Studies, (4), Pp 116-125.

[38] Ewelina B., Andrzej L., and Frédéric D., (2014). Effects of carbohydrate/protein ratio on the microstructure and the barrier and sorption properties of wheat starch-whey protein blend edible films. J. Sci. Food Agric, Pp (1-10), www.soci.org. 